\title{
The diversity and ethnobotanical study of medicinal plants in the southern slope of Mount Merapi, Yogyakarta, Indonesia
}

\author{
MAIZER SAID NAHDI", ARDYAN PRAMUDYA KURNIAWAN"^ \\ Program of Biology, Faculty of Science and Technology, Universitas Islam Negeri Sunan Kalijaga, Yogyakarta, Indonesia. Tel./fax.: +62-274560180, \\ •email: maizersn@yahoo.co.id; •vardyan89_ugm@yahoo.co.id
}

Manuscript received: 26 October 2019. Revision accepted: 24 July 2019.

\begin{abstract}
Nahdi MS, Kurniawan AP. 2019. The diversity and ethnobotanical study of medicinal plants in the southern slope of Mount Merapi, Yogyakarta, Indonesia. Biodiversitas 20: 2279-2287. Medicinal plants have been widely used by local communities in Indonesia due to its effectiveness as medicine and its low cost. In addition, the scientific and technological development of medicinal plants has been developed rapidly. This research aims to conduct inventory of medicinal plants recorded in the ecosystem of the southern slope of Mount Merapi, Yogyakarta and to reveal the local knowledge on their uses and traditional healing method applied. We used a combination of qualitative and quantitative methods. The data of local knowledge on medicinal plants and traditional medical practices when using them were collected through in-depth and semi-structured interview with local informants selected through purposive and snowball sampling. The results showed that the abundance of medicinal plant species at the study area was very high during the rainy season, while during the dry season, some of the plant species were found in the yard and open land. A total of 82 species from 40 families were identified as medicinal plants and used by the community through various processing and for various medical treatments. The information was inherited from previous generations through counseling and training. The most favorable way to use medicinal plants was by consuming the leaf directly. Among all identified medicinal plants, betel leaves (Piper betle L) had the highest importance value (43.6\%), followed by turmeric (Curcuma longa L) (38.5\%), and soursop (Annona muricata L) (33.3\%). Kelor (Moringa pterygosperma, Gaertn) had the most significant usage value $(0,6)$, followed by lemongrass (Cymbopogon citratus (DC) Stapf) and ginger (Curcuma xanthorrhiza Roxb) with the same value (0.3). The medicinal plants had also co-benefits including to encourage communication as well as to building relationship among community members.
\end{abstract}

Keywords: Favorite, importance value, side effects, snowball sampling, usage value

\section{INTRODUCTION}

Traditional healing is a part of cultural system that contributes greatly to improve public health. Moreover, the custom of utilizing plants to solve various health problems is in accord with the tendency to back to nature principle (Mamahani et al. 2016). Local knowledge has been widely recognized in the world (Kunwar and Rainer 2008) and has been implemented for thousands of years (Mondal et al. 2015). In some societies, medicinal plants are also more preferable for treatment than chemical drugs (Tinitana et al. 2016), as well as beneficial for biodiversity and cultural conservation. Traditional healing can also facilitate the discovery of new element extracted from a species that potential to be developed as new medicine (Mondal et al. 2015; Abbas et al. 2017).

The usage of traditional medicine for self-care tends to increase globally (Bussmann and Douglas 2006). In India, Nepal, and Africa, $80 \%$ of people use traditional medicine as the major treatment for diseases, while Columbian residents that use traditional medicine are up to $40 \%$ of its population (Bhandary and Chandrashekar 2014; Bussmann and Douglas 2006; Mondal et al. 2015; O’Neill and Rana 2016). Similar culture can also be found in Indonesia. In Bali, for example, there is loloh, a traditional herbal drink for treatment and health care (Sujarwo et al. 2015). Public awareness about medicinal plants has also increased through cultivation of crops and medicinal plants in garden, as commonly practiced by the Batak Karo community (Silalahi and Nisyawati 2018).

Medicinal herbs have been vigorously studied in Indonesia. Based on the local experiences that have been passed down for generations, traditional healing knowledge can help in determining the efficacy of medicinal plants in clinical research (Kuntorini 2005; Sujarwo et al. 2015; Abbas et al. 2017). The treatment using plants has also increasingly favored over chemical drugs due to some advantages, such as little to no side effects if it used properly, effective to cure various diseases, has affordable price, easy to find and can be used without the guidance from medical practitioners (Mondal et al. 2015; Nisyapuri et al. 2017; Suproborini et al. 2018).

Every community, ethnicity or tribe has different practices of traditional healing so that the knowledge produced varies. The knowledge of traditional healing in a community comes from the accumulation of interaction with natural environment in their living area and therefore, results in specific local wisdom (Purwanto 2017). For generations, the community living in the slopes of Mount Merapi has experienced many events of volcanic eruption of Mount Merapi hence they have a high sense of togetherness and mutual cooperation, which have still been preserved until now, as well as toughness in living life. Wonokerto is one of the villages located on the southern 
part of Mount Merapi slope. Located $4 \mathrm{~km}$ away from Mount Merapi, this village has fertile soil. Therefore, most of the people there live from agriculture and plantations. Despite technological advances, the values and wisdom of Wonokerto's community that have been passed down from generation to generation are still maintained, including the use of medicinal plants for health care. They have lived in harmony with nature for hundreds of years ago. This long experience has established local wisdom in various fields, including the knowledge of traditional healing or ethnobotany that remains to be preserved (Gunawan 2014). There have been some changes in the knowledge of traditional healing, along with the increasing of populated area in the southern part of Merapi slope as well as the presence of several higher educational institutions. This condition most likely affects the local wisdom about medicinal plants that have been preserved by the community. In addition, the medical counseling conducted by the government and private sectors can also affect the ethnobotanical knowledge in the community of Mount Merapi slope.

Despite the increasing research on medicinal plants in Indonesia (Setyowati 2010), the local knowledge of medicinal plants and their usage for traditional healing in the Mount Merapi communities have not been fully revealed. Community is one of the foremost actors in maintaining local wisdom. Therefore, research on the abundance and ethnobotany of medicinal plants on the southern part of Mount Merapi slope is very important to help preserving the local knowledge as well as to conserve the biodiversity in that area (Akerreta et al. 2007; Irsyad et al. 2013). This study aims to identify medicinal plants in the ecosystem of southern Mount Merapi, to reveal the information about the origin of local knowledge, and to analyze the utilization of various medicinal plants species for disease treatments.

\section{MATERIALS AND METHODS}

\section{Research period and location}

The research was conducted in February-July 2018 in the southern slope of Mount Merapi in Turi Sub-district, Sleman District, Yogyakarta Province, Indonesia, precisely at three hamlets within Wonokerto Village, namely Becici, Gondoarum, and Tunggularum hamlets. Those hamlets are located at the foot of Mount Merapi at about 4-6 km from the summit. The village has a total area of $15.58 \mathrm{~km}^{2}$, and borders the Girikerto Village in the north and the east, Donokerto Village in the south, and Srumbung Village of Magelang District in the west. Located around 398-976 meters above sea level, Wonokerto Village is located at the south latitude of $07^{\circ} 22^{\prime} 33$ "- $07^{\circ} 52$ ' $30^{\prime \prime}$ and the east longitude of $110^{\circ} 15^{\prime} 00^{\prime \prime}-110^{\circ} 37^{\prime} 30^{\prime \prime}$. The topography of the region is mostly hilly or mountainous with the rainfall of $3908 \mathrm{~mm} /$ year and average temperature of $24^{-2} 28^{\circ} \mathrm{C}$ (Figure 1).

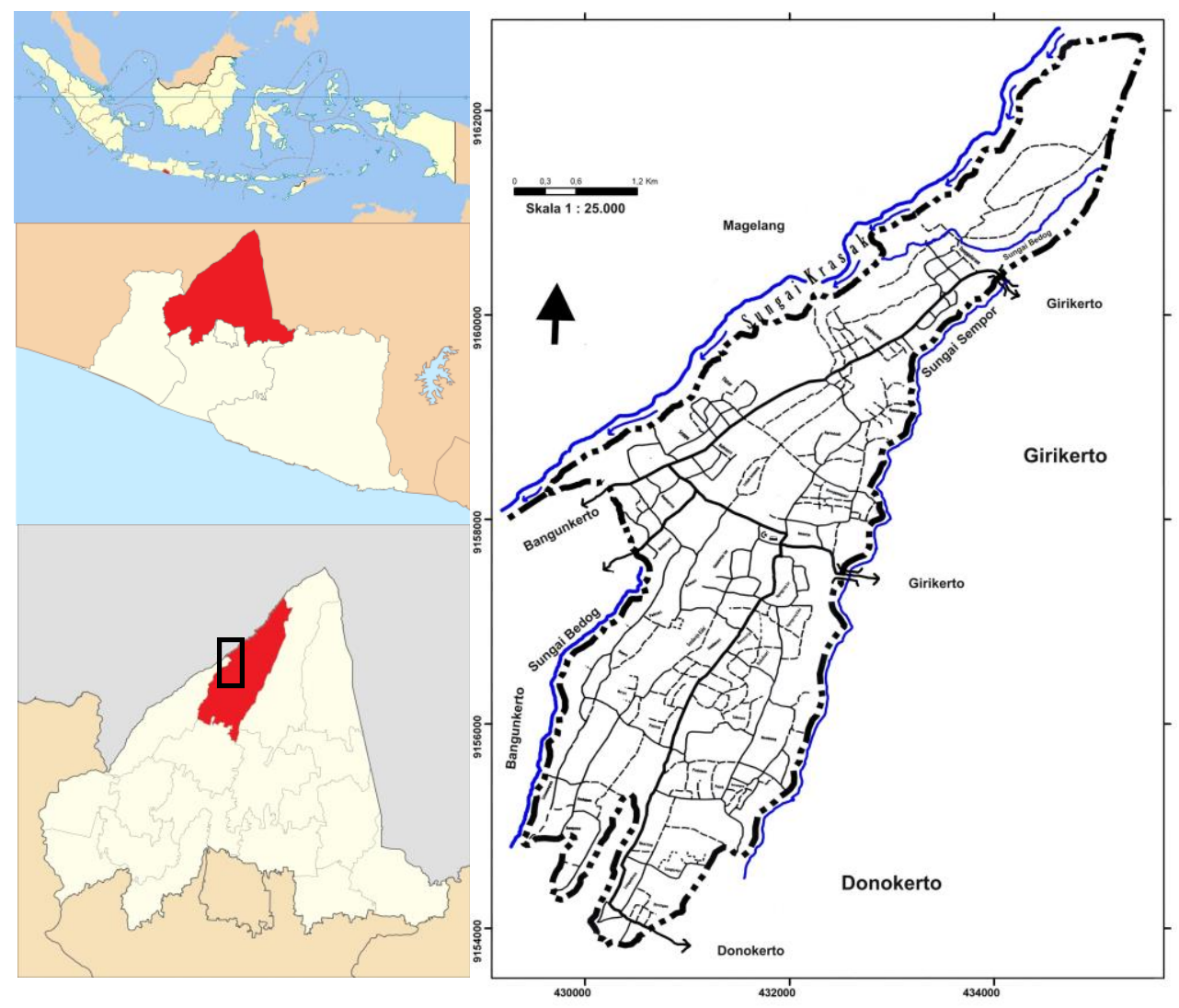

Figure 1. The study location at Wonokerto Village, Turi Sub-district, Sleman District, Yogyakarta Province, Indonesia 


\section{Data collection}

The data collected was about all medicinal plant species used by the Wonokerto people, including the part of the plant used, the usage method and its benefits, and also obtained from the member of community who actively used medicinal herbs in their daily life. The information on medicinal herbs usage was obtained from 39 respondents of the native of Wonokerto, who were selected by purposive sampling through snowball sampling. The snowball sampling was used to avoid choosing inappropriate respondent (Naderifar et al. 2017; Algethami et al. 2017).

The search of information was begun from the head of hamlet as the key informant, continued to the chairman of Dasa Wisma (A group of mothers from 10 families (family heads) of neighboring houses to facilitate the running of a program) and the people who actively involved in the medicinal plant utilization. The data was collected through in-depth and structured interview for later analysis in a qualitative and quantitative description. Medicinal herbs utilized by the people were identified using the books of Steenis (1972) and Backer et al. (1973). Meanwhile, the unidentified plants were photographed, made herbarium and taken to the laboratory of Botany and Ecology, at the Faculty of Science and Technology, UIN Sunan Kalijaga to be further identified by taxonomist.

The data of plant abundance was obtained by comparing the species acquired from its habitat to the purchased plants. The important value $(I V)$ was determined as the number of respondents who used a certain medicinal plant divided by the total number of respondents. The usevalue (benefit value) is the particular species most widely used for treatment by respondents compared to the total use of all species of medicinal plants (Purwanto 2017; Cotton 1996).

$$
\begin{array}{ll}
I V=\frac{N i}{\sum N} x 100 \% & \begin{array}{l}
\text { Where: } \\
\text { IV: Inportant value } \\
\text { Ni: Number of respondents using Species A } \\
\text { N: Total number of respondents }
\end{array} \\
U V=\frac{V i}{\sum V} & \begin{array}{l}
\text { Where: } \\
\text { UV: Use value / Benefit value } \\
\text { Vi: Use of species A } \\
\text { V: Total use of all species (Cotto 1996) }
\end{array}
\end{array}
$$

\section{The profile of respondents}

The respondents were considered as the representation of Wonokerto community who used medicinal plants (Figure 2). They were selected randomly from various profiles of gender, age, level of education, and employment. The percentage of female respondents was higher than male respondents (74\% and 26\%, respectively). The most active users of medicinal plants were the 45-55 years old people, and dominated by housewives and farmers $(95 \%)$. Based on the level of education, senior high school graduates were the highest $(49 \%)$ and followed by junior high school graduates (26\%). Only 5\% of respondents had undergraduate education. It showed that women were more active in utilizing medicinal plants for family health care. The dominant users of medicinal plants were the 45 years old people, while the young respondents under 25 years old who actively used medicinal plants were only $10 \%$. It indicated that the younger generation was less interested in using medicinal plants.

\section{RESULTS AND DISCUSSION}

\section{The origin of knowledge on medicinal plants}

The results of the interview showed that the knowledge on medicinal plants has been known by the community of Wonokerto since hundreds of years ago. In addition to the knowledge passed down from the elders, various sources of information included neighbors and friends $(38 \%)$, media $(11 \%)$, the medical team $(11 \%)$, self-try $(7 \%)$, counseling $(5 \%)$, baby shaman and massage shaman $(3 \%)$. Despite the low percentage, the counseling that mainly provided by LESAN from the Health Study Institute had been the most influential to motivate people to use medicinal plants (Figure 3).

The success of counseling in motivating people to be more active in utilizing medicinal plants related to the method used. It was initiated by the establishment of the Elderly Park in Tunggularum Village which engaged elderly people either male or female. The program provided counseling about the utilization, procurement of seeds and cultivation methods. The planting was conducted in the fields and the harvest was bought directly by LESAN to be processed into a ready-made herbal medicine, which afterward would be given back to the residents. The drug administration by LESAN was adjusted for the disease suffered by the residents, following a check-up every two weeks by medical personnel. Currently, LESAN is no longer active in Wonokerto Village, but the people continue to utilize and cultivate medicinal plants, either in the field or the home yard although the numbers are not as many as before. This is different from Bali, where the people are the one who plays significant role in the utilization of medicinal plants (Oktavia et al. 2017).

\section{The source and the community's perception of medicinal plants}

The medicinal plants in Wonokerto were mainly obtained from the yard (69\%), followed by the market or a selling stall $(12 \%)$, the fields $(18 \%)$ and the surrounding forests (1\%) (Figure 3). It showed that most medicinal plants were largely fulfilled from their own environment, suggesting that the abundance of medicinal plant species in Wonokerto was quite high, especially in the rainy season and decreased during the dry season. Medicinal plants were abundant because the location of Wonokerto was very close to Mount Merapi which facilitates the enrichment of nutrients from the eruption, resulting in fertile soils. This condition was also supported by the presence of many springs in Wonokerto that were well preserved. 


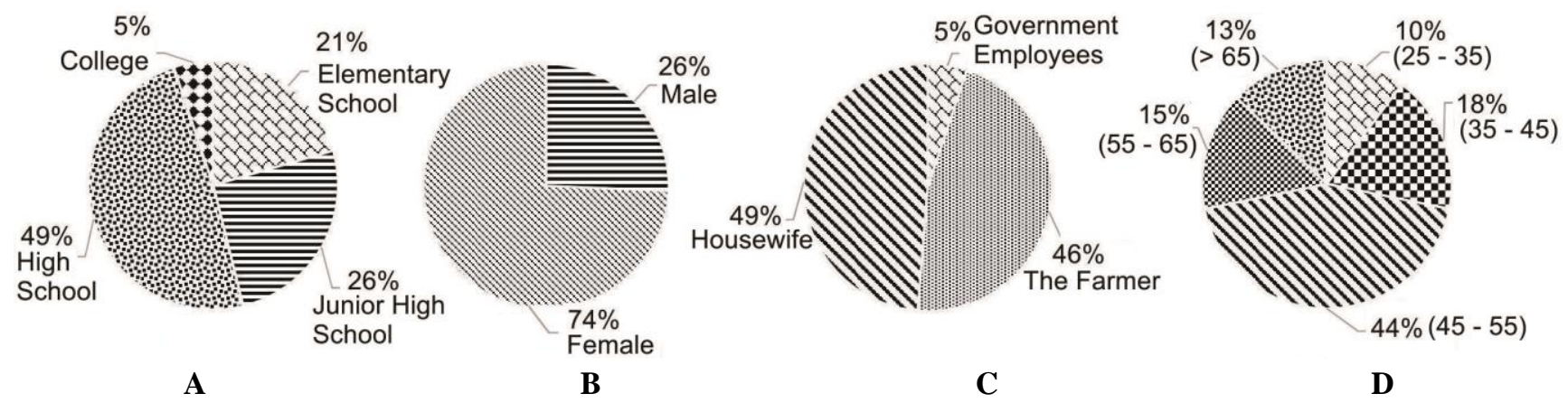

Figure 2. The profile of the respondents in the studied area based on: A. Education; B. Gender; C. Occupation; D. Age

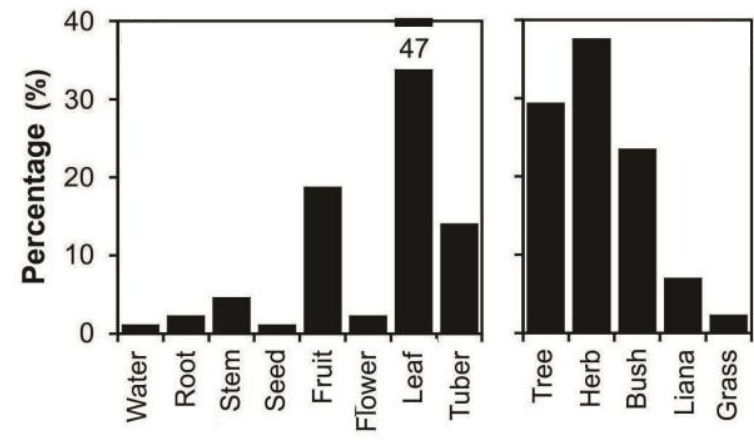

A

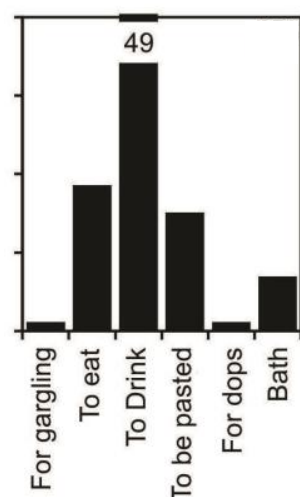

C

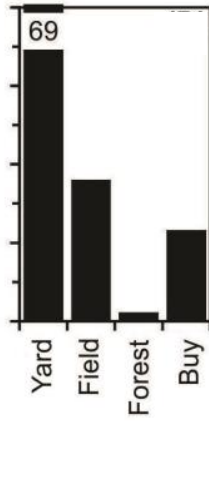

D

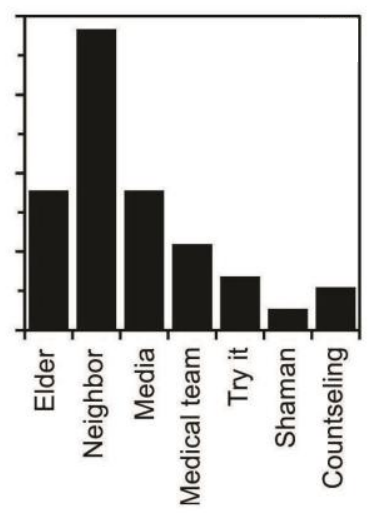

$\mathbf{E}$

Figure 3. The summary of information on medicinal plants in Wonokerto based on: A. The part of the plant being used; B. Habitus; C. How to use; D. The location where the plants being collected; E. The source of information obtained

We found that the abundance of medicinal plant species had not been utilized as a business commodity to improve the welfare as the community rather prioritized togetherness, cooperation and sharing. The community more concerned about family system because the land available for agriculture was still sufficient so that the medicinal plants were not for trading, but were freely given to relatives, close neighbors or someone else in need. These results are similar to the research conducted by Conde (2017) in Brazil, but different to the Nepali people. In Nepal, medicinal plants are traded commodities and 50\% of the people there rely on it for living (Kunwar and Rainer 2008).

\section{The habitus, the part and the serving method of medicinal plants}

The most dominant habitus used of medicinal plants in Wonokerto was herbaceous plant (38\%), followed by tree $(29 \%)$, shrub $(24 \%)$, liana $(7 \%)$ and grass $(2 \%)$ (Figure $3 \mathrm{~B})$. This is similar to the results on the medicinal plants found in the Jakholi block, Himalayan India that comprised of $56 \%$ of herbaceous plant, $23 \%$ of tree and $37 \%$ roots (Sing 2017). On the other hand, the most widely used part of the plant was leaf $(55 \%)$, followed by fruit (19\%), tuber
(14\%), stem (5\%), and roots, water, seeds and flowers (each accounted for 1-2\%) (Figure 3.A). This result is similar with the study in Sinjai District, Indonesia in which the leaf is the highest plant part used, followed by rhizome and stem, while the fruit used for medicine only a few (Sari et al. 2017). The leaves as the most used part for medicine are also revealed in the Wonoharjo Village, Pangandaran, West Java and Kampong Dukuh (Hidayat et al. 2010; Nisyapuri et al. 2017). This is because they believe that the leaves have the highest efficacy, easy to obtain, do not damage the trees and easily sprout again, as well as having soft fibers. In addition, the leaves are one of the organs that contain high carbohydrates, minerals, and vitamins, and also easily found (Abbas 2017; Setyowati and Wardah 2007; Sing 2017). However, it is different from the results obtained in Jeju Island, which reporting the roots as the most widely used part for medicinal purposes, followed by fruit, leaves, and seeds (Song et al. 2013).

The use of medicinal plant for herbal drinks was the most favorite usage serving method by the community (49\%). The herbal drink was easily made and treated diseases more quickly. The other way was to eat it directly or being boiled/burned first $(19 \%)$, pasted and smeared $(15 \%)$, used for bathing or soaking $(7 \%)$, and used for 
gargling and dropping (1\% each) (Figure 5). This result is similar to the results obtained in Mecca in which drinking $(63 \%)$ is the most common serving method, followed with being eaten $(21 \%)$, pasted $(7 \%)$, pasted directly on the teeth $(2 \%)$, and in small quantities used for lotion, for rubbing and washing (Algethami et al. 2017).

\section{The diversity of medicinal plants}

The people in Wonokerto recognized and utilized 84 medicinal plant species that belong to 40 families (Table 1). Those plants were used to cure various diseases including digestion, respiratory, reproductive, endocrine, muscles and joints as well as excretion, circulatory, supplements, skin, and beauty (Table 2). The number of species found in Wonokerto is higher than those found in Turgo Village that located $7 \mathrm{~km}$ from the summit of Merapi, which consists of 69 species from 36 families (Maizer et al. 2016), as well as higher than the medicinal plants found in Wawonii Island which has 73 species from 43 families (Rahayu et al. 2006), and in Pakistan with 64 species from 41 families (Aziz et al. 2018). However, it is fewer than medicinal plant species found in Kampong Adat Dukuh, Garut Regency, West Java, which has 150 species from 52 families (Hidayat et al. 2010) and the western Pyrenees with 91 species (Akerreta et al. 2007).

Zingiberaceae (7 species) was the most widely used family, followed by Asteraceae and Lamiaceae, each of which consisted of 5 species (Table 1). The study in Turgo Hill has also similar result, with 6 species each, belong to Zingiberaceae and Asteraceae, followed by 5 species from Euphorbiaceae (Maizer et al. 2016). In Adat Dukuh, Zingiberaceae family dominates with 16 species having used for medicinal purposes (Hidayat et al. 2010). However, different result is found by Algethami (2017) in Mecca which shows that the most family used is Apiaceae, followed by Fabaceae and Lamiaceae. Also in the Eastern Himalayas, Asteraceae is the most used family, followed by Polygonaceae, Rosaceae, and Zingiberaceae (Sing 2017).

The species from Zingiberaceae $(8.33 \%)$ that were used for medicine in Wonokerto consisted of: (i) Temu ireng (Curcuma aeruginosa Roxb), a herbaceous plant that is used by boiling the tuber and then drink the water to relieve abdominal pain; 9ii) Temulawak (Curcuma xanthorrhiza Roxb) is utilized for gastrointestinal pain including ulcer, typhus, and intestinal thickening; (iii) Laos (Alpinia galanga (L) Willd) is utilized to treat skin diseases, mainly tinea versicolor, by making it into puree and then smear it; (iv) White turmeric (Kaempferia rotunda $\mathrm{L}$ ) is boiled to prevent and reduce lumps; (v) Turmeric (Curcuma longa) is used to cure digestion and painful menstrual periods; (vi) Kencur (Kaempferia galanga (Linn.) is used for respiratory disease, especially cough and the shortness of breath. Turmeric is made into puree, and the water is squeezed and then drinking with honey or egg yolks. It is also used for muscle and joint pain, i.e. sprains, by mashing and smearing turmeric paste in the pain area; (vii) Ginger (Zingiber officinale Roscoe) is especially used as a supplement to increase stamina and warm the body. Ginger is roasted, pounded or boiled and drink. It is also used to treat muscular pain and rheumatic by grinding and smearing the paste on the pain area (Table 2). Ginger is used by 32 respondents from a total of 39 people $(82 \%)$. The people in Mecca also use ginger to treat muscle and joints, in addition, to treat indigestion, cardiovascular and endocrine, and to increase stamina (Abbas et al. 2017). On the other hand, the people in the area of Lake Buyan use ginger in a balm mixture to warm the body, to treat scorpion sting and rheumatism (Octavia et al. 2017). Ginger is widely used in traditional healing, mostly to warm body and to cure cold, due to its flavonoid content. The flavonoid in ginger can activate multi-enzyme systems, such as cytochrome P-450 and B5 that affect the metabolism of lipids and bile acids (Hapsari and Hesti 2014), hence keeps the body warm and relieves cold.

The second most used family was Asteraceae with 5 species (6\%) with species including (i) Sambung nyawa (Ginura procumbent (Blume) Miq) which is used for joints and muscles (gout and rheumatism). It is also used to treat endocrine and digestive pain, lowering blood sugar and reducing gastric acid. Five leaves are boiled with one glass of water until the water is reduced to half and being drink while still warm; (ii) Sintrong (Crassocephalum crepidioides (Benth.) S. Moore) is used to treat digestion problem, mainly to treat flatulence. This usage was a result of selftrying and it was successful; (iii) Sumber waras/insulin (Tithonia diversifolia (Hemsl) is used to lowering blood sugar (endocrine) of which insulin leaves are brewed with hot water for herbal drink; (iv) Tapak liman (Elaphantopus scaber Linn.) is used to heal muscles and joints (rheumatism) by making it into paste and smeared it to the pain area; (v). Tempuyung (Sonchus arvensis) is used to expedite urinary secretion and shed kidney stone.

Lamiaceae had also similar rank with Asteraceae with 5 species, which consisted of: (i) Teak (Tectona grandis L. f), is used to treat digestive pain (e.g. diarrhea). The stem is roasted and then put into a hot tea; (ii) Basil (Ocimum citriodorum Vis.) is used for skin and beauty care, mainly to remove body odor by consuming the raw leaves; (iii) Kumis kucing (Orthosiphon stamineus Benth.) is used for the excretion of pain by shedding kidney stones through boiling the plant and drink the water; (iv) Leng lengan (Leucas lavandulifolia Smith) is used to treat digestive diseases, especially intestinal worms. The leaves are ground and applied to the stomach; (v) Remujung (Orthosiphon aristatus (Blume) Miq.) is used to cure excretory disease through expediting urinary secretion and shedding kidney stones by boiling the leaves and drink the water.

In addition to being utilized as medicine, the people in Wonokerto Village use certain plants to reduce pollution and prevent diseases. Lidah mertua (Sansevieria trifasciata Prain), for example, is used to reduce air pollution, both outdoor and indoor, especially pollution caused by carbon monoxide from cigarette smoke (Haerani et al. 2016). Lemongrass (Cymbopogon citratus (DC.) Stapt) is used to reduce mosquito population. The ethanol extract from lemongrass leaves and stem can be used as pesticides to control Aedes aegypti mosquitoes since it contains saponin, tannins, quinone and steroid (Hendrik et al. 2013). 
The species with the highest importance value was betel (Piper betle L) which is used by 17 out of 39 respondents in total (43.6\%), followed by ginger (Zingiber officinale Roscoe) with a value of $38.5 \%$ or used by 15 respondents, and soursop (Annona muricata $\mathrm{L}$ ) with a value of $33.3 \%$ or used by a third of respondents. Meanwhile, the other species had values between 5\%-20\%. Piper betle is a medicinal plant species that has been widely used in China and India, many of which is used to cure microbial infections on the oral cavity (Pradhan et al. 2015). Betel leaf has been widely used as a chewing material and is considered beneficial for respiratory and oral hygiene. This plant has high medicinal properties because it contains tannins, chavicol, phenyl, and propane so that it is also used for treating digestion, as an expectorant, stimulant, anti-bacterial and to stimulate euphoria (Dasgupta and Bratati 2016). Another species with a highly important value, soursop, is a member of Annonaceae family that has been used by the people for a long time. It has many benefits, including as an anticancer, anticonvulsant, antiarthritic, antiparasitic, antimalarial, antidiabetic, antiinflammatory and immune-booster (Patel and Patel 2016)

Table 1. The family and the number of species of medicinal plants in Wonokerto Village, Turi Sub-district, Sleman District, Yogyakarta, Indonesia

\begin{tabular}{lc}
\hline Family & Number of species \\
\hline Acanthaceae & 3 \\
Amaryllidaceae & 2 \\
Annonaceae & 1 \\
Apiaceae & 3 \\
Apocynaceae & 1 \\
Araceae & 2 \\
Araliaceae & 1 \\
Arecaceae & 3 \\
Asteraceae & 5 \\
Lauraceae & 3 \\
Basellaceae & 1 \\
Brassicaceae & 2 \\
Bromeliaceae & 1 \\
Campanulaceae & 1 \\
Caricaceae & 1 \\
Cucurbitaceae & 4 \\
Euphorbiaceae & 2 \\
Fabaceae & 3 \\
Iridaceae & 1 \\
Lamiaceae & 5 \\
Liliaceae & 2 \\
Marantaceae & 1 \\
Menispermaceae & 1 \\
Meliaceae & 1 \\
Moraceae & 1 \\
Moringaceae & 1 \\
Musaceae & 1 \\
Myrtaceae & 4 \\
Oxalidaceae & 1 \\
Phyllanthaceae & 1 \\
Piperaceae & 3 \\
Poaceae & 2 \\
Portulacaceae & 1 \\
Rosaceae & 1 \\
Rubiaceae & 3 \\
Rutaceae & 4 \\
Sapotaceae & 2 \\
Simaroubaceae & 1 \\
Zingiberaceae & \\
\hline & \\
& \\
\hline
\end{tabular}

Table 3. The grouping of diseases regarding the uses of medicinal plants by Wonokerto community, Yogyakarta, Indonesia

\begin{tabular}{|c|c|}
\hline Disease categories & The name of disease \\
\hline \multirow{9}{*}{ Digestive } & Ulcer/stomach \\
\hline & Typhus \\
\hline & Intestinal thickening \\
\hline & Flatulence/stomachache \\
\hline & Sprue \\
\hline & Toothache \\
\hline & Intestinal worms \\
\hline & Diarrhea \\
\hline & Hemorrhoid \\
\hline Endocrine & Diabetes \\
\hline \multirow[t]{9}{*}{ Muscles and joints } & Gout \\
\hline & Sore muscles \\
\hline & Sprains \\
\hline & Arthritis \\
\hline & Waist pain \\
\hline & Pinched nerves \\
\hline & Stroke \\
\hline & Vertigo \\
\hline & Headache \\
\hline \multirow{9}{*}{ Senses and Beauty } & Sore eyes \\
\hline & Wounds \\
\hline & Chickenpox \\
\hline & Itching \\
\hline & Tine versicolor \\
\hline & Allergies \\
\hline & Boils \\
\hline & Hair loss \\
\hline & Body Odor \\
\hline \multirow[t]{4}{*}{ Respiratory } & Cough \\
\hline & Nosebleeds \\
\hline & Shortness of breath \\
\hline & Mumps \\
\hline \multirow[t]{5}{*}{ Reproduction } & Menstruation \\
\hline & Breast milk \\
\hline & Vaginal discharge \\
\hline & Vaginal hygiene \\
\hline & Vaginal itching \\
\hline \multirow[t]{2}{*}{ Excretion } & Urinary secretion \\
\hline & Kidney stones \\
\hline \multirow[t]{9}{*}{ Circulatory } & Hypertension \\
\hline & Anemia \\
\hline & Hypotension \\
\hline & Cholesterol \\
\hline & Heart \\
\hline & Cleanse the blood \\
\hline & Increase platelets \\
\hline & Dengue fever \\
\hline & Accelerate blood circulation \\
\hline \multirow[t]{7}{*}{ Supplements } & Warm the body/stomach \\
\hline & Boosts stamina \\
\hline & Preventing cancer \\
\hline & Antioxidant \\
\hline & Appetite \\
\hline & Child Intelligence \\
\hline & Antiseptic \\
\hline \multirow{2}{*}{$\begin{array}{l}\text { Pollution \& } \\
\text { environment }\end{array}$} & Eliminates cigarette smoke odor \\
\hline & Reduce mosquito population \\
\hline
\end{tabular}


Table 2. The list of medicinal plants in Wonokerto Village, Turi Sub-district, Sleman District, Yogyakarta, including the family name, latin name, local name and their benefits.

\begin{tabular}{|c|c|c|c|}
\hline Family & Species & Local name & Benefits \\
\hline \multirow[t]{3}{*}{ Acanthaceae } & Graptophyllum pictum (L.) Handle & Ambien & Hemorrhoids \\
\hline & Justicia gendarussa Burm. F. & Ganda rusa & Headache \\
\hline & Strobilanthes crispa Blume & Keji beling & Expediting urinary secretion, sore muscles \\
\hline \multirow[t]{2}{*}{ Amaryllidaceae } & Allium sativum $\mathrm{L}$. & Bawang putih/garlic & Heart, blood circulation \\
\hline & Allium cepa $\mathrm{L}$. & Brambang/onion & Warming up the body \\
\hline Annonaceae & Annona muricata $\mathrm{L}$. & Sirsak/soursop & Hypertension \\
\hline \multirow{3}{*}{ Apiaceae } & Foeniculum vulgare Mill & Adas & Fever \\
\hline & Centella asiatica (L.) Urban & Pegagan/regedeg & Sore muscles \\
\hline & Apium graveolens $\mathrm{L}$. & Seledri/celery & Hypertension \\
\hline Apocynaceae & Catharanthus roseus $\mathrm{L}$. & Tapak dara putih & Lowering blood sugar \\
\hline \multirow[t]{2}{*}{ Araceae } & Colocasia esculenta (L.) Schott & Lompong & Wounds \\
\hline & Alocasia plumbea K. Koch ex Van Houtte & Lompong ireng & Typhus \\
\hline Araliaceae & Polyscias scutellaria (Burm.f.) Fosberg & Mangkokan & Lowering high blood pressure \\
\hline \multirow{3}{*}{ Arecaceae } & Cocos nucifera $\mathrm{L}$. & Degan serat merah & Shedding kidney stone \\
\hline & Arenga pinnata (Wurmb) Merr. & Kolang-kaling & Arthritis \\
\hline & Salacca zalacca (Gaert) Voss & Salak pondoh & Hypertension \\
\hline \multirow[t]{5}{*}{ Asteraceae } & Gynura procumbens (Lour.) Merr & Sambung nyawa & Sore muscles \\
\hline & Crassocephalum crepidioides (Benth.) S. Moore & Sintrong & Flatulence \\
\hline & Tithonia diversifolia (Hemsl) A. Gray & Sumber waras/insulin & Diabetes \\
\hline & Elephantopus scaber L. & Tapak liman & Sore muscles \\
\hline & Sonchus arvensis $\mathrm{L}$. & Tempuyung & $\begin{array}{l}\text { Expediting urinary secretion and shedding } \\
\text { kidney stone }\end{array}$ \\
\hline Basellaceae & Anredera cordifolia (ten) Steenis & Binahong & Wounds and sore muscles \\
\hline \multirow[t]{2}{*}{ Brassicaceae } & Raphanus sativus $\mathrm{L}$. & Lobak/radish & Gout and sore muscles \\
\hline & Brassica rapa $\mathrm{L}$. & Sawi hijau & Sore eyes \\
\hline Bromeliaceae & Ananas phyaces (L.) Merr & Nanas/pineapple & Gout and sore muscles \\
\hline Campanulaceae & Laurentia longiflora (L.) Peterm & Katarak & Sore eyes \\
\hline Caricaceae & Carica papaya $\mathrm{L}$. & Pepaya/papaya & Hypotension \\
\hline \multirow[t]{4}{*}{ Cucurbitaceae } & Sechium edule (Jacq.) Sw. & Jipang putih & Fever \\
\hline & Cucumis melo $\mathrm{L}$. & Melon & Hypertension \\
\hline & Citrullus lanatus (Thunb.) Matsum & Semangka/watermelon & Hypertension \\
\hline & Cucumis sativus $\mathrm{L}$. & Timun/cucumber & Hypertension \\
\hline \multirow{2}{*}{ Euphorbiaceae } & Aleurites moluccana (.) Willd & Kemiri & Gout and sore muscles \\
\hline & Euphorbia tirucalli L. Rubber & Tikel balung & Sprains \\
\hline \multirow{3}{*}{ Fabaceae } & Erythrina variegata $\mathrm{L}$. & Cangkring & Chickenpox \\
\hline & Leucaena leucocephala (Lam.) de Wit & Petai Cina & Itching \\
\hline & Parkia speciosa Hassk & Petai & Itching \\
\hline Iridaceae & Eleutherine bulbosa (Mill.) Urb & Brambang brojol & Headache, sore muscles \\
\hline \multirow{4}{*}{ Lamiaceae } & Tectona grandis Linn. F. & Jati/teak & Diarrhea \\
\hline & Ocimum citriodorum Vis. & Kemangi/basil & Eliminate body odor \\
\hline & Leucas lavandulifolia Smith. & Leng lengan & Worm disease \\
\hline & Orthosiphon aristatus (Blume) Miq. & Kumis kucing/cat whisker & $\begin{array}{l}\text { Expediting urinary secretion and shedding } \\
\text { kidney stone }\end{array}$ \\
\hline \multirow[t]{3}{*}{ Lauraceae } & Litsea glutinosa (lour. ) C.B Rob & Adem-adem ati & Lowering blood pressure \\
\hline & Persea americana Mill. & Alpukat/Avocado & Lowering blood pressure \\
\hline & Cinnamomum verum J.Presl & Kayu manis/Cinnamon & Lowering high blood pressure \\
\hline \multirow[t]{2}{*}{ Liliaceae } & Sansevieria trifasciata Prain. & Lidah mertua & Removing cigarette smoke odor \\
\hline & Aloe vera Mill. & Lidah buaya & Wounds caused by hot oil \\
\hline Marantaceae & Maranta arundinacea $\mathrm{L}$ & Garut & Stomach ailments \\
\hline Meliaceae & Azadirachta indica A. Juss. & Mimba & Muscle clamping \\
\hline Menispermaceae & Tinospora crispa (L.) Miers ex. Hoff.f & Brotowali & Itching or allergies \\
\hline Moraceae & Morus alba $\mathrm{L}$. & Murbei/mulberry & Sore muscles, headache \\
\hline Moringaceae & Moringa oleifera Lamk & Kelor & $\begin{array}{l}\text { Vitamins, sore muscles, increasing breast } \\
\text { milk production, lowering cholesterol, } \\
\text { hypertension, improve blood flow, to cure } \\
\text { witchcraft }\end{array}$ \\
\hline & Musa acuminata Colla & Pisang mas/banana & Fever \\
\hline \multirow[t]{4}{*}{ Myrtaceae } & Eugenia uniflora L. & Dewandaru & Cough \\
\hline & Psidium guajava $\mathrm{L}$. & Jambu buji/guava & Diarrhea \\
\hline & Syzygium malaccense (L.) Merr. \& Perry & Jambu susu & Diarrhea \\
\hline & Syzygium polyanthum (Wight) Walp. & Salam & Lowering cholesterol \\
\hline
\end{tabular}




\begin{tabular}{|c|c|c|c|}
\hline Oxalidaceae & Averrhoa bilimbi $\mathrm{L}$ & Belimbing wuluh & Cough \\
\hline Phyllanthaceae & Sauropus androgynus (L) Merr & Katuk & Increasing breast milk production \\
\hline \multirow[t]{3}{*}{ Piperaceae } & Piper betle L. & Sirih/betel & Relieves cough \\
\hline & Peperomia pellucida $\mathrm{L}$. & Sirih cina & Gout \\
\hline & Piper ornatum L. & Sirih merah & Toothache \\
\hline \multirow[t]{2}{*}{ Poaceae } & Imperata cylindrica Raeusch & Alang-alang & Waist pain \\
\hline & Cymbopogon citratus (DC.) Stapf & Sereh/lemongrass & $\begin{array}{l}\text { Increasing stamina, anti-cancer, and } \\
\text { reducing mosquito populations }\end{array}$ \\
\hline Portulacaceae & Portulaca oleracea L. & Krokot & Vertigo \\
\hline Rosaceae & Rosa sp. L. & Mawar/rose & Cough \\
\hline \multirow[t]{3}{*}{ Rubiaceae } & Uncaria gambir (Hunt.) Roxb. & Gambir & Stomach, typhus \\
\hline & Coffea arabica Lind. & Kopi/coffee & Gout \\
\hline & Morinda citrifolia $\mathrm{L}$. & Pace & Hypertension and cough \\
\hline \multirow[t]{4}{*}{ Rutaceae } & Citrus limon (L.) Osbeck & Jeruk lemon/lemon & Antioxidant \\
\hline & Citrus aurantifolia (Christm.) Swingle & Jeruk nipis/lime & Sprue \\
\hline & Citrus hystrix DC. & Jeruk purut & Fever \\
\hline & Citrus amblycarpa (Hassk.) Ochse & Jeruk uwik & Fever \\
\hline \multirow[t]{2}{*}{ Sapotaceae } & Manilkara zapota (L.) P. Vikraman & Sawo & Diarrhea \\
\hline & Manilkara kauki (L.) Dubard & Sawo kecik & Diarrhea \\
\hline Simaroubaceae & Brucea javanica (L.) Mess & Mekasar & Diarrhea \\
\hline \multirow{7}{*}{ Zingiberaceae } & Zingiber officinale Roscoe & Jahe/ginger & Warming the body \\
\hline & Kaempferia galanga $\mathrm{L}$. & Kencur & Relieves cough \\
\hline & Curcuma longa $\mathrm{L}$. & Kunir/turmeric & Stamina enhancer \\
\hline & Curcuma alba $\mathrm{L}$. & Kunir putih/white turmeric & Prevents lumps \\
\hline & Alpinia galanga $(\mathrm{L}$.) SW. & Laos & Lord \\
\hline & Curcuma aeruginosa Roxb & Temu ireng & Abdominal pain \\
\hline & Curcuma xanthorrhiza Roxb & Temulawak & Ulcer, typhus, intestinal thickening \\
\hline
\end{tabular}

Kelor (Moringa pterygosperma Gaertn) was revealed as a species with the highest usage value (0.6). It was used as a vitamin or supplement, and to treat sore muscle, to increase the production of breast milk, to reduce cholesterol and high blood pressure, to improve blood flow, to eliminate witchcraft, and to remove tingling sensation by using boiled or cooked leaves. High nutritional content in all organs of kelor, especially in the leaves, makes kelor has high medicinal properties for health care and can also be used to overcome nutritional deficiencies. Therefore, kelor is called the Miracle Tree and Mother's Best Friend (Aminah et al. 2015). The species with the next highest value was lemongrass (Cymbopogon citrates (DC.) Stapf. and temulawak (Curcuma xanthorrhiza Roxb) with the same value of 0.3 . Whereas, the other species had a relatively small value, ranged between 0.1-0.2.

Mostly, the use of medicinal plants for healing has not been empirically proven so that the dosage and composition still need to be studied and developed further. In addition to health care, medicinal plants have high potential to be utilized as alternative sources of income for the people (Kunwar and Rainer 2008). Eventually, the existence of local wisdom can contribute to biodiversity conservation (Adnan and Othman 2010).

In summary, the people of Wonokerto possess knowledge on the utilization of medicinal plants which has been passed down from generation to generation. They have known and used 84 medicinal plant species from 40 families. Zingiberaceae was the family consisting of the most used species ( 7 species), while betel (Piper betle $\mathrm{L}$ ) was the most important species, followed by ginger
(Zingiber officinale Roscoe) and soursop (Annona moricata L). Kelor (Moringa pterygosperma Gaertn) was species with the most benefits followed by lemongrass (Cymbopogon citrates (DC.) Stapf) and temulawak (Curcuma xanthorhiza roxb). The leaf was the most used plant part, specifically for making herbal drinks (oral). The habitus of plants used for medicinal purposes were mostly herbaceous plants, and the plants were largely obtained from the house yard. The utilization of medicinal plants facilitates to strengthen the social relationship, sharing, and mutual cooperation in society. The processing of medicinal plants was still conventional, hence requiring further research, especially in pharmacological aspects, so that the composition and dosage can be measured accurately. However, the community needs to be continuously motivated to improve and develop the local knowledge in line with technological developments.

\section{ACKNOWLEDGEMENTS}

Authors would like to give the biggest appreciation to the people of Wonokerto Village especially the members of Dasa Wisma from Becici, Tunggularum and Gondoarum hamlets for providing information about local knowledge on traditional healing and medicine. Also, thanks Lurah Wonokerto, Tomon Haryo Wirosobo for issuing the research permit. Authors would also like to thank Husna Syifa Sanni and Ismi Nur Diyanah for their help in collecting and tabulating data. 


\section{REFERENCES}

Abbas Z, Shujaul MK, Jan A, Sher WK, Astriad MA. 2017. Medicina plant used by inhabitant of the Shigar Valley, Baltistan region of Karakaroum range, Pakistan. J Ethnobiol Ethnomed 13:53. DOI: 10.1186/s13002-017-0172-9.

Adnan N, Othman N. 2010. The Relationship between Plant and The Malay Culture. Procedia-Soc Behav Sci 42 (2012): 231-241

Akerreta S, Cavero RY, Calvo MI. 2007. First comprehensive contribution to medical ethnobotany of Western Pyrenees. J Ethnobiol Ethnomed 3 (1): 26. DOI: 10.1186/1746-4269-3-26

Alqethami A, Julie AW, Irene TT. 2017. Medicinal plant used by women in Mecca: urban, Muslim and gendered knowledge. J Ethnobot Ethnomed 13: 62. DOI: 10.1186/s13002-017-0193-4.

Aminah S, Tezar R, Muflihani Y. 2015. Kandungan Nutrisi dan Sifat Fungsional Tanaman Kelor (Moringa oleifera). Buletin Pertanian Perkotaan 5 (2): 35-44. [Indonesian]

Aziz MA, Muhammad A, Amir HK, Abdelaaty AS. 2018. Traditional uses of medicinal plants practiced by the indigenous communities at Mohmand Agency, FATA, Pakistan. J Ethnobiol Ethnomed 14: 2. DOI: 10.1186/s13002-017-0204-5.

Backer CA, van Steenis CGGJ, Backer CA. 1973. Atlas of 220 weeds of sugar-cane fields in Java. Indonesian Sugar Experiment Station, Pasuruan.

Bhandary MJ, Chandrashekar KR. 2014. Diversity and use of ethnomedicinal plants in coastal Karnataka, India. Biodiversitas 15 (1): 89-93

Bussmann RW, Douglas S. 2006. Traditional medicine plant use in Northern Peru: tracking two thousand years of healing culture. J Ethnobiol Ethnomed 2: 47. DOI: 10.1186/1746-4269-2-47.

Conde BE, Tamara ASF, Arthur LM, Timothy OO, Luciana MC. 2017. Local ecological knowledge and its relationship with biodiversity conservation among two Quilombola groups living in the Atlantic Rainforest, Brazil. PloS One. DOI: 10.1371/journal.pone.0187599

Cotton CM. 1996. Ethnobotany: Principle and Applications. John Wiley \& Sons, Chichester.

Dasgupta N, Bratati D. 2016. Antioxidant activity of Piper betle L. lea extract in vitro. Food Chem 88 (2): 219-224.

Gunawan G. 2014. Study Ethnobotany Andong Plants of the Genus Cordyline in the Dayaknese of Meratus Lok Lahung Village, Loksado, South Borneo. Proc Int Conf Glob Resour Conserv 4 (1) 17-19.

Haerani N, Arayani, Nurhasanah, Novianti A, Ince RN. 2016, Inovas Produk Sanseviera Sebagai Pengharum dan Penyerap Asap. Jurnal Pena 3 (2): 1-9. [Indonesian]

Hapsari H, Hesti MR. 2014. Pengaruh Pemberian Jahe Merah (Zingiber officinale var rubrum) Terhadap Kadar kolesterol LDL Wanita Dislipidemia. J Nutr Coll 3 (4): 871-879.

Hendrik WG, Erwin, Aman SP. 2013. Pemanfaatan tumbuhan serai wangi (Cymbopogon nardus (L) Rendle) sebagai antioksidan alami. Jurna Kimia Mulawarman 10 (2): 74-79. [Indonesian]

Hidayat S, Agus H, Zuhud EAM. 2010. Ethnobotanical study of Loca People at Dukuh Cultural Village Garut Regency, West Java. Media Konservasi 15 (3): 139-151. [Indonesian]

Irsyad MN, Jumari, Murningsih. 2013. Ethnobotany study of Rural Community Sukolilo, Kendeng Mountains, Pati, Central Java. Bioma 15 (1): 27-34. [Indonesian]

Kuntorini. 2005. Botani ekonomi suku Zingeberaceae sebagai oba tradisional oleh masyarakat di Kota Madya Banjarbaru. Bioscience 2 (1): 25-36. [Indonesian]

Kunwar RM, Rainer WB. 2008. Ethnobotany in Nepal Himalaya (Review). J Ethnobiol Etnomed 4:24. DOI: 10.1186/1746-4269-4-24.
Maizer SN, Nugraheni IAM, Disca CA. 2016. The ethnobotany of medicinal plants in supporting the family health in Turgo, Yogyakarta, Indonesia. Biodiversitas 17 (2): 900-906.

Mamahami AF, Herny EI, Simbala, Saroyo. 2016. Etnobotani tumbuhan obat masyarakat Subetnis Tonsawang di Kabupaten Minahasa Tenggara, Provinsi Sulawesi Utara. Pharmacon Jurnal Ilmiah Farmasi 5 (2): 205-212. [Indonesian]

Mondal K, Arghya P, Salman H. 2015. Ethnobiological And Traditional medicine Practices in Burdwan District, West Bengal, India. Int J Ethnobiol Ethnomed 19 (1): 1-8.

Naderifar M, Goli M, Ghaljaei F. 2017. Snowball Sampling: A Purposeful Methods od Sampling in Qualitative Research. J Med Educ Dev Cent 14 (3): 1-6.

Nisyapuri FF, Iskandar J, Partasasmita R. 2018. Study of ethnobotany of medicinal plants in Wonoharjo Village, Pangandaran District, West Java. Pros Sem Nas Masy Biodiv Indon 4: 122-132. [Indonesian]

O'Neill AR, Rana SK. 2016. An ethnobotanical analysis of parasitic plants (Parijibi) in the Nepal Himalaya. J Ethnobiol Ethnomed 12 (1): 14. DOI: 0.1186/s13002-016-0086-y.

Oktavia GAE, I Dewa PD, Wawan S. 2017. Ethnobotanical study of medicinal plants in the area around Buyan-Tamblingan. Buletin Kebun Raya 20 (1): 1-16. [Indonesian]

Patel S, Patel JK. 2016. A. Review on a Miracle fruits of Annona muricata L. J Pharmacogn Phytochem 5 (1): 137-148.

Pradhan D, Suri KA, Pradhan DK, P. Biswasroy. 2015. Golden Heart of Nature: Piper Betle L. J Pharmacogn Phytochem 1 (6): 147-167.

Purwanto Y. 2017. (unpublish). Etnobotani Indonesia. Pusat Penelitian Biologi, Lembaga Ilmu Pengetahuan Indonesia (LIPI), Bogor. [Indonesian]

Rahayu M, Sunarti S, Diah S, Suhardjono P. 2006. Traditional use of medicinal herbs by local community of Wawonii island, Southeast Sulawesi. Biodiversitas 7 (3): 245-250. [Indonesian]

Sari N, Wahidah BF, Gaffar AA. 2017. Etnobotani Tumbuhan yang Digunakan Dalam Pengobatan Tradisional di Kecamatan Sinjai Selatan, Kabupaten Sinjai, Sulawesi Selatan. Prosiding Seminar Nasional Biology for Life: 6-13.

Setyowati FM, Wardah. 2007. Diversity of medicinal plant by Talang Mamak tribe in surrounding of Bukit Tiga Puluh National Park, Riau. Biodiversitas 8 (3): 228-232. [Indonesian]

Setyowati FM. 2010. Etnofarmakologi dan pemakaian tanaman obat suku dayak tunjung di Kalimantan Timur. Media Penelitian dan Pengembangan Kesehatan 20 (3 Sept). [Indonesian]

Silalahi M, Nisyawati. 2018. The Ethnobotanical study of edible and medicinal plants in the home garden of Batak Karo subethnic in North Sumatra, Indonesia. Biodiversitas 19 (1): 229-238.

Sing A, Mohan CN, Ripu MK, Rainer W. B. 2017. Ethnomedicinal plants used by local inhabitants of Jakholi block, Rudrapayag District Westwrn Himalaya, India. J Ethnobiol Ethnomed 13: 49.

Song MJ, Brian H, Jongwook J, Sanghun L. 2013. Ethnopharmacological survey of medicinal plant in Jeju Island, Korea. J Ethnobiol Ethnomed 9: 48. DOI: 10.1186/1746-4269-9-48.

Steenis CGGJ van. 1972. Mountain Flora of Java. E.J. Brill, Leiden.

Sujarwo W, Keim AP, Savo V, Guarrera PM, Caneva G. 2015. Ethnobotanical study of Loloh: Traditional herbal drinks from Bali (Indonesia). J Ethnofarmakologi 169: 229-238.

Suproborini A, Laksana MSD, Yudiantor F. D. 2018. Ethnobotany Antipyretic Plants Peoples in Dusun Mesu Boto Jatiroto Wonogiri Central Java. J Pharm Sci Med Res 1 (1): 1-11.

Tinitana F, Rios M, Romero-Benavides JC, de la Cruz Rot M, Pardo-deSantayana M. 2016. Medicinal plants sold at traditional markets in southern Ecuador. J Ethnobiol Ethnomed 12 (29): 1-18. 